Karpenko Oleksandr, D. Sc. (Public Administration), Chairman of Information Policy and Digital Technologies Faculty, National Academy of Public Administration, under the President of Ukraine ORCID 0000-0002-9301-7973 dr.karpenko@ukr.net;

\title{
FORMATION AND REALIZATION OF PARTICIPATIVE CULTURE IN THE CONDITIONS OF THE DIGITAL SOCIETY DEVELOPMENT: COMMUNICATIVE GOVERNANCE AND CYBERHYGIENE
}

The purpose of the work is the implementation of the scientific and theoretical substantiation of the mechanisms of formation and implementation of participatory culture in the conditions of the digital society development. Research Methodology. The research uses general scientific and special methods, in particular: the inductive and deductive method, the method of analysis and synthesis, the dialectical method, the method of system and structural-functional analysis, the nomothetic and ideographic method. Scientific novelty lies in substantiation of the significance of communicative governance as a determining environment for influencing the formation of a participatory culture, and cyber hygiene as the basic element of its implementation in the conditions of the digital society development. Conclusions. The global tendencies of formation of modern communicative management in the conditions of network (digital) society development are analyzed. It is determined that the technological significance of digital technologies is rapidly changing to social, which contributes to the formation of a new participatory culture. It has been established that cyber hygiene has no signs of statehood or privacy, and therefore the digital awareness and literacy of citizens is the basis of counteracting manipulative influence of cybercriminals. It is proved that information psychological weapons are a destructive means of influencing mass consciousness / unconsciousness, therefore, the visual task for the proper functioning of digital society is to master each individual with effective means of protection against manipulation - the norms and rules of cyber hygiene.

Key words: participatory culture, networking society, communicative governance, social media, information security, digital society, digital personalization, digital hygiene, digital technologies, digital services, cyber security, cyber hygiene, cyberbullying, cybersquatting.

Карпенко Олександр Валентинович, доктор наук з державного управління, завідувач кафедри інфрормаційної політики та цифрових технологій Національної академії державного управління при Президентові України

Формування та реалізація партисипативної культури в умовах розвитку цифрового суспільства: комунікативне управління та кібергігієна

Метою роботи $є$ здійснення науково-теоретичного обґрунтування механізмів фрормування та реалізації партисипативної культури в умовах розвитку цифрового суспільства. Методологія дослідження. У дослідженні використано загальнонаукові й спеціальні методи, зокрема: індуктивний та дедуктивний метод, метод аналізу та синтезу, діалектичний метод, метод системного та структурно-функціонального аналізу, номотетичний та ідеографічний метод. Наукова новизна полягає в обґрунтуванні сутності комунікативного управління як визначального середовища впливу на формування партисипативної культури, а кібергігєни як базового елементу її реалізації в умовах розвитку цифрового суспільства. Висновки. Проаналізовано глобальні тенденції формування сучасного комунікативного управління в умовах розвитку мережевого (цифрового) суспільства. Визначено, що технологічне значення цифрових технологій стрімко змінюється на соціальне, що сприяє формуванню нової партисипативної культури. Встановлено, що кібергігієна не має ознак державності чи приватності, а тому основою протидії маніпулятивному впливу кіберзлочинців є цифрова обізнаність та грамотність громадян. Доведено, що інформаційнопсихологічна зброя $є$ руйнівним засобом впливу на масову свідомість/несвідомість, тому наочним завданням щодо належного функціонування цифррового суспільства є оволодіння кожним індивідом ефрективними засобами захисту від маніпулювання - нормами та правилами кібергігєни.

Ключові слова: партисипативна культури, мережеве суспільство, комунікативне управління, соціальні медіа, інформаційна безпека, цифрове суспільство, цифрова партисипація, цифрова гігієна, цифрові технології, цифрові сервіси, кібербезпека, кібергігієна, кібербулінг.

Карпенко Александр Валентинович, доктор наук государственного управления, заведующий кафедрой инфрормационной политики и цифровых технологий Национальной академии государственного управления при Президенте Украины

Формирование и реализация партисипативной культуры в условиях развития цифрового общества: коммуникативное управление и кибергигиена

Целью работы является осуществление научно-теоретического обоснования механизмов формирования и реализации партисипативный культуры в условиях развития цифрового общества. Методология исследования. При исследовании использованы общенаучные и специальные методы, в частности: индуктивный и дедуктивный метод, метод анализа и синтеза, диалектический метод, метод системного и структурно-фрункционального анализа, номотетический и идеографиический метод. Научная новизна заключается в обосновании значення коммуникативного управления как определяющей среды влияния на формирование партисипативной культуры, а кибергигены как базового элемента ее реализации в условиях развития цифрового общества. Выводы. Проанализированы глобальные тенденции формирования современного коммуникативного управления в условиях развития сетевого (цифрового) общества. Определено, что технологическое значение цифровых технологий стремительно меняется на социальное, что способствует формированию новой партисипативный культуры. Установлено, что кибергигиена не имеет признаков государственности или приватности, а поэтому основой противодействия манипулятивному воздействию киберпреступников является цифровая осведомленность и грамотность граждан. Доказано, что информационно-психологическое оружие является разрушительно средством воздействия на массовое сознание/бессознательное, поэтому основной задачей обеспечения надлежащего функционирования цифрового общества является освоение каждым индивидом эффрективных средств защиты от манипулирования - норм и правил кибергигены.

Ключевые слова: партисипативная культура, сетевое общество, коммуникативное управления, социальные медиа, информационная безопасность, цифровое общество, цифровая партисипация, цифровая гигиена, цифровые технологии, цифровые сервисы, кибербезопасность, кибергигиена, кибербуллинг. 
Relevance of the research topic. The problem of the formation of a modern participatory culture in Ukraine has the particular relevance in the process of developing the digital economy and society. The phenomenon of the emergence of digital participation is associated with the actualization of citizens' participation in their initiative in the formation and implementation of public policy, development of public administration and local government, which involves the interactive interaction of decision-making subjects with the use of digital technologies in cyberspace in accordance with the established rules and norms of digital hygiene

Scientific coverage of the problem. Scientific discourse is about the formation of rules and procedures for the application of communicative governance mechanisms in a networked society, the emergence and functioning of which in their writings were thoroughly investigated by G. Simmel, J. V. Dijk, M. Castells [1] ta J. Martin. The problem of forming a participatory culture is poorly investigated in Ukraine, unlike the EU and the US. In this context, we should mention the works of such scholars as K. Clinton, C.Chau. C. Fuchs [2], H. Jenkins [3], R. Puroshotma, A. Robison, M. Weigel, P.Willis. Interaction in cyberspace, cybersecurity and behavioral component of each of the subjects of the digital society is based on observance of certain norms and rules of network behavior (cyber hygiene), the basis of which are digital competences (knowledge and skills), proper education, as well as social, cultural and national values.

Problem statement. The unresolved part of the general problem is the lack of scientific and theoretical substantiation of mechanisms for the formation and implementation of participatory culture in the conditions of the digital society development.

Methodology of the study. The research uses general scientific and special methods, in particular: the inductive and deductive method, the method of analysis and synthesis, the dialectical method, the method of system and structural-functional analysis, the nomothetic and ideographic method.

Theoretical basis and results. The research considers the global trends in the formation of modern communicative administration in the development of network (digital) society. These trends have different degrees of influence and expression in the process of interaction between government and the public, the participation of citizens in the adoption of managerial decisions. They integrate effective methods of one sphere into another. The influence of visual civilization prevails over the verbal. A modern person prefers to consume informational content through digital gadgets. The technological significance of digital technology is rapidly changing to a social one, which contributes to the formation of a new participatory culture.

M. Zuckerberg in an open letter to investors stated: "technologies that have revolutionized how people spread and consume information ... Facebook aspires to build the services that give people the power to share and help them once again transform many of our core institutions and industries" [4]. Printing and television have increased the effectiveness of mass communications due to the ability to "hear" the providers (the subjects of administration). Subsequently, network technologies and digital communication tools have achieved other revolutionary changes - all the surfers, who have access to the Internet, including social networks, can "be heard". Ordinary users began to distribute what they considered necessary. Even now, Artificial-Intelligence (Al) produces narratives [5], while the popular YouTube video hosting, which features social networking features, is an ideal place for anyone on the Internet to download, store, view, distribute, evaluate, and comment on video information. The youtube.com site, which makes people become media creators, is the second most popular in the world after google.com, especially among young people. Today, YouTube is a modern media platform that produces a new, participative culture, in which young people can develop, interact and learn. All this deprives the state of a monopoly of influence on people, which leads to a weakening of the power of the authorities to manage social processes.

Communicative administration, thanks to the use of the Internet, video blogs and social networks, is carried out in an environment of accelerated information exchange. It should be noted that consumers do not have time to adequately perceive and absorb large volumes of information. This contributes to the emergence of the majority of "fake", through which there is a manipulation of public opinion. Modern technological development leads to certain negative consequences. For example, the speed of the transfer of information also has undesirable consequences, as negative content (misinformation, myths, fabrications, distorted stereotypes, fake) spreads instantly among millions of consumers. It affects the mass consciousness and subconsciousness. Memes, fake images, distorted visualization of facts and events distort the perceived by people.

The global communicative space has expanded significantly due to the Internet and social media, which has led to a total increase in the number of sources of information. In early 2018, the number of active Facebook accounts amounted to 2.13 billion, and in 2019 it increased to 2.7 billion, which is twice as much as in early 2012 . Ordinary social networking users independently produce any counter-content, destroying stereotypes that have traditionally created mass media for a long time. For social network users, this content is the main source of news. Each account becomes the access point of the segmenter to the user and - a means of personalized influence on each active user of the network (voter, gamer, buyer, consumer), which is typical of the digital society.

The massive fakes production is due to the lack of actual policy owners of social networks, through which the power of the vast majority of countries of the world can censor the content of social media (social groups). The application of the methodology of interference with the digital technologies usage and information space of the Internet is carried out through offensive information operations, for example, in order to interfere with the electoral process of other countries. Digital election intervention services are an effective tool for manipulating the mass consciousness / unconscious that is used by political technologists through the formation of the necessary stereotypes of the Facebook, Google+, Linkedln, Twitter, Classmates, VKontakte, and YouTube user segments. 
Increasing awareness of cybersecurity, dissemination of general rules of cyber defense and the conditions of everyday digital hygiene, explanatory and educational campaigns today are relevant both for the authorities and for the whole Ukrainian society. No state, commercial or public organizations are able to solve the problem of the effective implementation of information security autonomously, and therefore, each user must take part in ensuring the protection of their part of information and cyber space, starting with their own mobile devices and networks, which he uses. Private employees of any organization should become the "first line" of protection against cyber attacks.

Modern cybercriminals use not only encryption, but mostly legal and open Internet services in order to hide their actions and quietly overcome traditional cyber defense systems. It is proved that $80 \%$ of the cyberattack is done to steal user credentials that are used with one-factor authentication (login password). In addition, cyber attacks with the use of social engineering occur when a psychologist manipulates authentication data during personal communication with the user. Criminals use the fact that the vast majority of citizens do not have a sufficient level of digital culture, are unprepared and ignorant of the consequences of modern cyber threats. Society should realize that the Internet, digital media and services are resources of joint responsibility, and information security is a mechanism for ensuring the effective functioning of citizens.

It should be noted that the lack of a proper level of participatory culture in society contributes to the emergence of such a negative phenomenon as Internet addiction, which is rapidly spreading in the world based on behavioral ontological dependence of adults and children. Unfortunately, it is the children who are the most vulnerable social group of society, and therefore, the impact on their consciousness and unconsciousness in many countries is a real danger to their lives activity. In the countries of the former USSR, the level of children's Internet addiction reached $10 \%$, and the victims of cyberbullying were children, who fell into the communities of "Blue Kits" and "Red Owls". Minor and infamous "Momo" virus, which in the form of games is distributed in the WhatsApp and Telegranm messengers, was attacked.

The scientific novelty. It is substantiated that communicative administration is the determining medium of influence on the formation of a participatory culture, and cyber hygiene is the basic element of its realization in the conditions of the digital society development.

Conclusion. As a result of the study of the peculiarities of the formation and implementation of participatory culture in the conditions of the digital culture development, the following conclusions are proposed:

1. The global tendencies of formation of modern communicative administration in the conditions of network (digital) society development are analyzed. It is determined that the influence of visual civilization prevails over verbal, and the technological significance of digital technologies is rapidly changing to social, which contributes to the formation of a new participatory culture.

2. It has been proved that the ruling elite of any country, that is before the authorities, will always be tempted to manage the people' instincts by manipulating their consciousness. Information and psychological weapons are the most destructive means of influencing mass consciousness / unconsciousness, therefore, the visual task for the proper digital society functioning is to master each individual with effective means of protection against manipulation - the norms and rules of cyber hygiene.

3. It has been established that cyber hygiene has no signs of statehood or privacy, and therefore the digital awareness and literacy of citizens is the basis of counteracting manipulative influence of cybercriminals. Cyber hygiene is part of digital education, which should start from childhood: in school, lyceum, pre-school and extra-curricular institutions, etc. It is necessary to provide training for young people and children on the basis of information security, participatory culture and cyber hygiene, provide enough information on the use of passwords, the setting of digital services for mobile gadgets and computers, the use of preventive measures when using both home Internet and public networks (WI-FI).

\section{תimepamypa}

1. Castells M. (2010) The Information Age: Economy, Society and Culture Volume 1: The Rise of the Network Society. 2nd ed. Oxford: Wiley Blackwell. $625 \mathrm{p}$.

2. Fuchs C. (2014) "Social Media as Participatory Culture", Social Media: A Critical Introduction, SAGE Publications Ltd, pp. 52-68.

3. Jenkins, Henry, Puroshotma, Ravi, Clinton, Katherine, Weigel, Margaret, \& Robison, Alice J. (2005) Confronting the Challenges of Participatory Culture: Media Education for the 21st Century, available at http://www.newmedialiteracies.org/wpcontent/uploads/pdfs/NMLWhitePaper.pdf.

4. Zuckerberg M. (2012) Zuckerberg's letter to investors / Mark Zuckerberg // URL: www.reuters.com/article/us-facebookletter/zuckerbergs-letter-to-investors-idUSTRE8102MT20120201

\section{References}

1. Castells M. (2010) The Information Age: Economy, Society and Culture Volume 1: The Rise of the Network Society. 2nd ed. Oxford: Wiley Blackwell [in English].

2. Fuchs C. (2014) Social Media as Participatory Culture, Social Media: A Critical Introduction, SAGE Publications Ltd, $52-68$ [in English].

3. Jenkins, Henry, Puroshotma, Ravi, Clinton, Katherine, Weigel, Margaret, \& Robison, Alice J. (2005) Confronting the Challenges of Participatory Culture: Media Education for the 21st Century, available at http://www.newmedialiteracies.org/wpcontent/uploads/pdfs/NMLWhitePaper.pdf. [in English].

4. Zuckerberg, M. (2012) Zuckerberg's letter to investors / Mark Zuckerberg. URL: www.reuters.com/article/us-facebookletter/zuckerbergs-letter-to-investors-idUSTRE8102MT20120201 [in English]. 